\title{
Ultrastructure of Ebola virus particles in human liver
}

\author{
D. S. ELLIS, D. I. H. SIMPSON, D. P. FRANCIS, J. KNOBLOCH, \\ E. T. W. BOWEN, PACIFICO LOLIK, AND ISAIAH MAYOM DENG
}

From the London School of Hygiene and Tropical Medicine, UK; the Department of Microbiology, Harvard School of Public Health, USA; the Tropeninstitut, Hamburg, West Germany; the Microbiological Research Establishment, Porton, Wilts, UK; and the Regional Ministry of Health, Juba, Sudan

SUMMARY Electron microscopy of tissues from two necropsies carried out in the Sudan on patients with Ebola virus infection identified virus particles in lung and spleen, but the main concentrations of Ebola particles were seen in liver sections. Viral precursor proteins and cores were found in functional liver cells, often aligned in membrane-bound aggregations. Complete virions, usually found only extracellularly, were mainly seen as long tubular forms, some without cores. Many tubular forms had 'enlarged heads' or 'spores' and some branched and torus forms were identified. The size and structure of the Ebola virus forms appear to be virtually indistinguishable from those of Marburg virus.

Two almost simultaneous outbreaks of severe and often fatal viral haemorrhagic fever occurred in the Western Equatorial Province of southern Sudan and some 600 miles (964 kilometres) away in the Equator region of northern Zaire in the second half of 1976. Over 500 cases with some 350 deaths were reported. Virus strains isolated from Sudanese and Zairean patients (Johnson et al., 1977; Bowen et al., 1977; Pattyn et al., 1977) were structurally identical with Marburg virus strains isolated in Germany in 1967 (Siegert et al., 1967) and South Africa in 1975 (Gear et al., 1975) but antigenically quite distinct. The name Ebola virus has been given to the new prototype (Johnson et al., 1977).

In Sudan the epidemic affected mainly two townships, Nzara and Maridi, where 284 cases and 151 deaths were recorded, the largest number of cases (213) occurring in Maridi (Francis et al., 1978): 76 members of Maridi hospital staff were infected and 41 of them died. Severe bleeding from multiple sites was a common feature of the illnesses, the clinical details of which are reported by Smith et al. (1978).

Because the infections were so severe and the risk to hospital staff so great very few laboratory investigations or necropsies were carried out. Two necropsies were eventually performed at Maridi

Received for publication 12 September 1977 hospital by three of us and samples of various tissues were collected for virological, histopathological, and electronmicroscopic study. The histopathological findings have been reported by Ridley et al. (1978). We report in this paper the electron microscope findings in human tissue sections.

\section{Material and methods}

The necropsies were carried out respectively four and seven hours after death. The cadavers were of a young adult female and a young adult male. Those performing the necropsy followed the strict precautions suggested by Simpson (1977). The material examined was from the liver, kidney, spleen, and lung. Four-millimetre cubes were cut from all four organs and placed in phosphate-buffered glutaraldehyde in sealed containers. Six months later one-millimetre cubes were cut from the edges of all the original specimens and washed in repeated changes of Palade/sucrose buffer at $\mathrm{pH} 7 \cdot 4$ for 18 hours. The washed specimens were then postfixed in $1 \%$ osmium tetroxide in the same buffer for two hours and washed for a similar time in distilled water. Dehydration was done in graded methanols, specimens spending 30 minutes in $3 \%$ uranyl acetate in $30 \%$ methanol. Embedding was in Araldite via graded propylene oxide mixtures. After polymeration for 48 hours at $60^{\circ} \mathrm{C}$ sections were cut on a Cambridge Huxley Ultramicrotome and stained with 
lead citrate before viewing on either a Zeiss EM 9A or AE1 EM 801 (for the higher magnifications).

\section{Results}

Much of the material was poorly preserved, no doubt partly because of the delayed necropsy. Some virions were found in the capillaries of the lung and spleen but not in the tissues of these organs or in those of the kidney. The main concentrations of the Ebola particles were confined to the liver, where large aggregations were easily seen among the dying hepatic cells (Figs 1 and 3) and in the bile canaliculi (Fig. 2).

Few inclusion bodies were identified and no viral arrays of complete particles were seen. However, viral precursor material and cores were occasionally seen lined up within vacuoles. Unidentified but distinctive structures (Fig. 2) appeared to be associated with areas of new virus production from membranes and vacuoles.

Branched forms (Figs 6, 7, 8) tended to be congregated into certain infected areas, whereas the 'enlarged heads' (Figs 3, 4, 15, 16) were found among all the viral groups seen. In some areas of the infected liver many of the particles contained no cores (Figs 9, 10, 11), while long particles lacking cores along parts of their length (Fig. 14) were common. Coiled ends (Fig. 12) were occasionally found, together with those in torus form (Fig. 17). Multiple cores, two to six in number (Fig. 4), within a single coat were also encountered. The complete virion in its tubular form measured 75 to $80 \mathrm{~nm}$ in diameter (Fig. 5), its projections adding perhaps a further 15 to $20 \mathrm{~nm}$. Within this lay the core, 35 to $40 \mathrm{~nm}$ in diameter, whose centre appeared as a hollow tube of approximately $18 \mathrm{~nm}$. The torus was more variable in size but most were within the range of 250 to $300 \mathrm{~nm}$ (Figs 15, 16, 17). The pitch of the nucleic acid core measured $7.5 \mathrm{~nm}$ (Fig. 15). Figure 13 shows the spikes on the outer membrane. The periodicity of these was not easy to measure in these cut sections (Fig. 13) but appeared to be about 12 to $15 \mathrm{~nm}$.

\section{Discussion}

Recent work on Ebola virus (Pattyn et al., 1977; Bowen et al., 1977; Johnson, et al., 1977) has shown that this virus is morphologically similar to Marburg virus (Murphy et al., 1971; Peters et al., 1971; Almeida et al., 1971). In comparing the two agents Johnson et al. stated that there were no known morphological differences, though their particles were antigenically distinct. Our studies of the Ebola agent within human tissues, and without using subculture or negative staining, supported the firs conclusion. All our measurements and forms weres within the ranges of those found in the previous studies on Marburg virus (Almeida et al., 1971, ando others).

We found that the statement in areas where the original order of cell organelles still can be recog nised, complete virions can only be discerned in extracellular positions' (Peters et al., 1971), made originally about Marburg infections of monkeys $\vec{\xi}$ was generally applicable to Ebola agents in humane liver. However, precursor stores of the cores of this? agent are to be found within apparently stilliw functioning liver cells and, like those found in experimental infections of Marburg virus (Murphyin et al., 1971), are aligned in membrane-bound aggregations. But in our material they were made ups of individual groups too small to be designated asarrays.

The completed virions, made by the incorporation of membranes from the surface through which the cores were extruded, were mainly in the long, $\overrightarrow{0}$ tubular form, as found by Johnson et al. (1977). However, these membrane-covered tubes did not always contain cores (Fig. 11), suggesting perhapsड their independent production. Almeida et al. (1971) suggested that for Marburg virus the torus was the final mature form. We found few of these forms, but other structures (Figs 15 and 16) resembling 'spores' on the end of the tubular form were common. Possibly these 'enlarged heads' may be an intermediate stage in torus formation, and Figs 15, 16, and 17 perhaps show the stages in this process Figure 15 shows the nucleic acid core beginning too curl up within an 'enlarging' head. The pitch of this core, $7.5 \mathrm{~nm}$, accords well with the measurement:of $7.8 \mathrm{~nm}$ made by Almeida et al. (1971) during negative staining studies on the Marburg agent. Figure 16 represents the next stage, with the complete torus formed but still attached to the main tubular $>$ body. In Fig. 17 a 'tag', the remains of the attachment to the main body, can still be seen on middle torus form.

The interval between the spikes, measured again using negative staining methods, on the Marburg $\omega$ agent by Peters et al. (1971) was recorded as $10 \mathrm{~nm}$.? Our finding of $15 \mathrm{~nm}$ for Ebola virus would need을 further studies of fresh negatively stained material before any significant difference could properly be ${ }^{-}$ established.

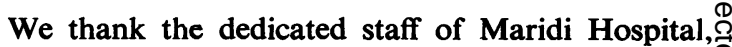
Sudan, together with Miss Susan Stamford, David $\mathbb{Q}$ Day, and Michael Smith of the London School of Hygiene and Tropical Medicine for their help ando technical assistance. 

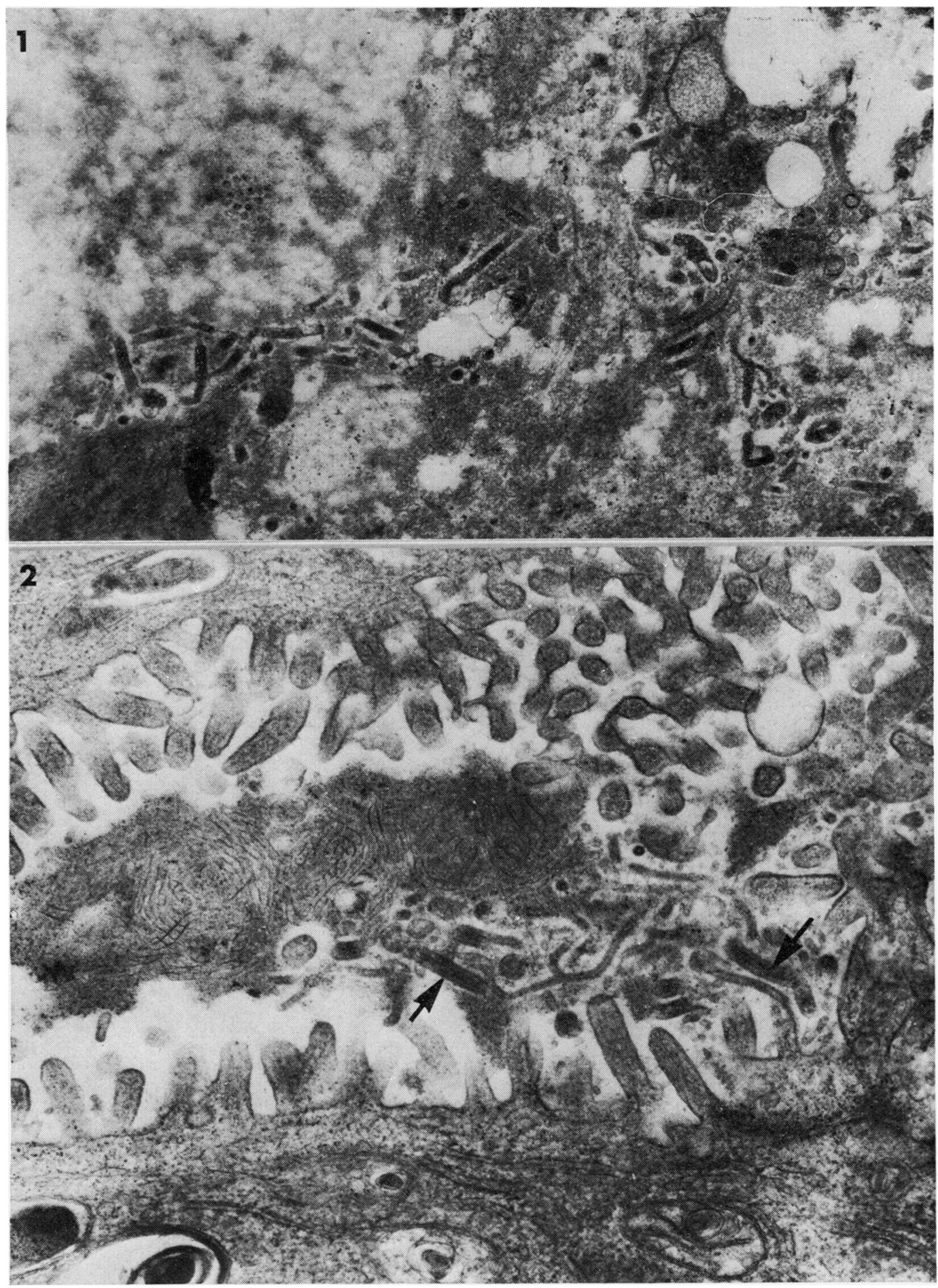

Fig. 1 General (low magnification) view of Ebola virus particles, mainly in tubular form, lying among destroyed liver cells. $(\times 20000)$

Fig. 2 Virus particles extruded into bile canaliculus; note some branched and many incomplete. Two complete virions arrowed. Striated material lying within the lumen is usually associated with virions. $(\times 42000)$ 


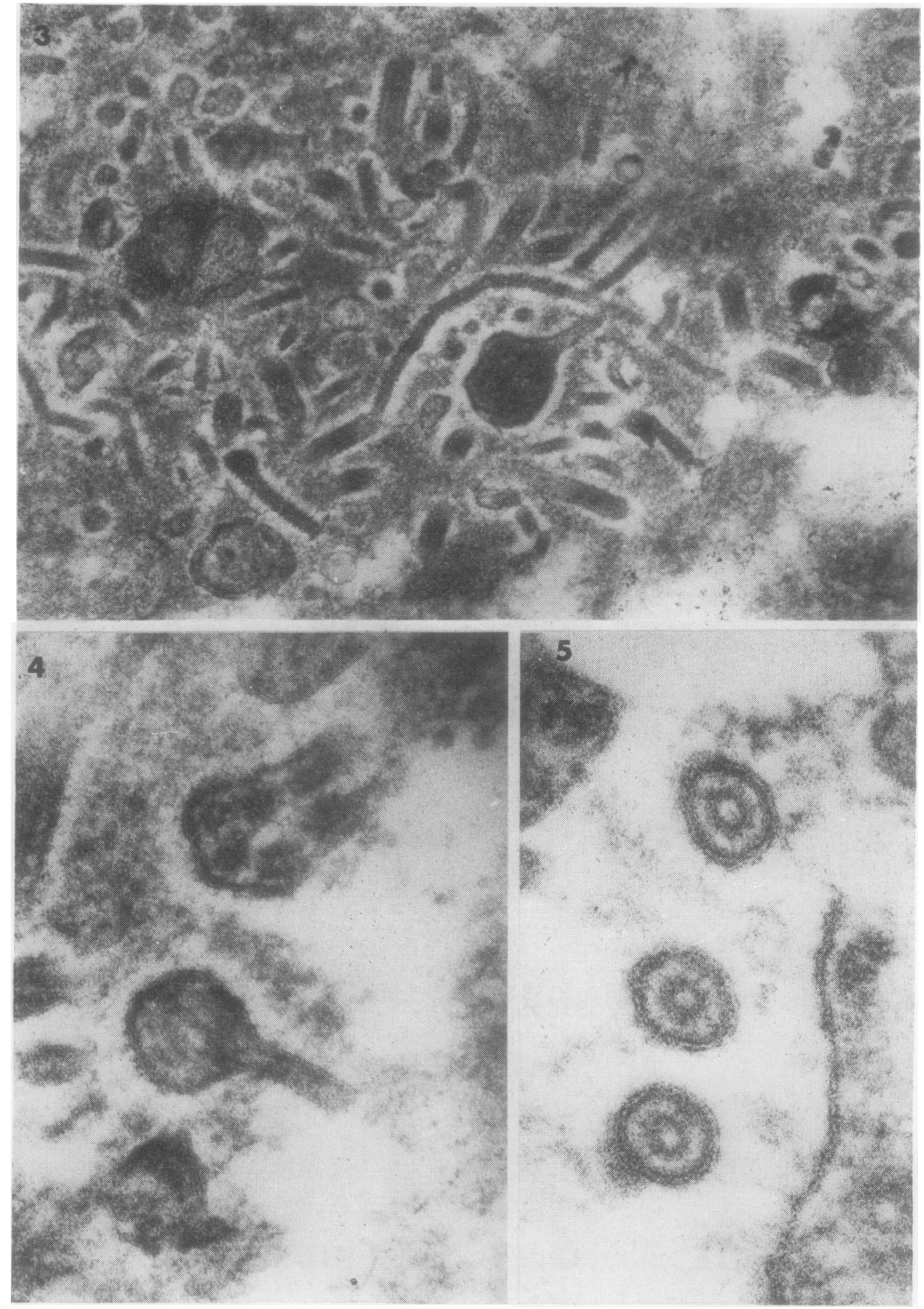

Fig. 3 Higher magnification of area similar to that in Fig. 1, with 'enlarged head' in centre and occasional torus. Many virions are incomplete. $(\times 50000)$

Fig. 4 'Enlarged head' and oblique section through tubular form containing six nucleic acid cores. $(\times 126000)$ Fig. 5 Cross-sections of three virions showing hollow cores within outer membrane. Spikes are not visible. $(\times 200000)$ 

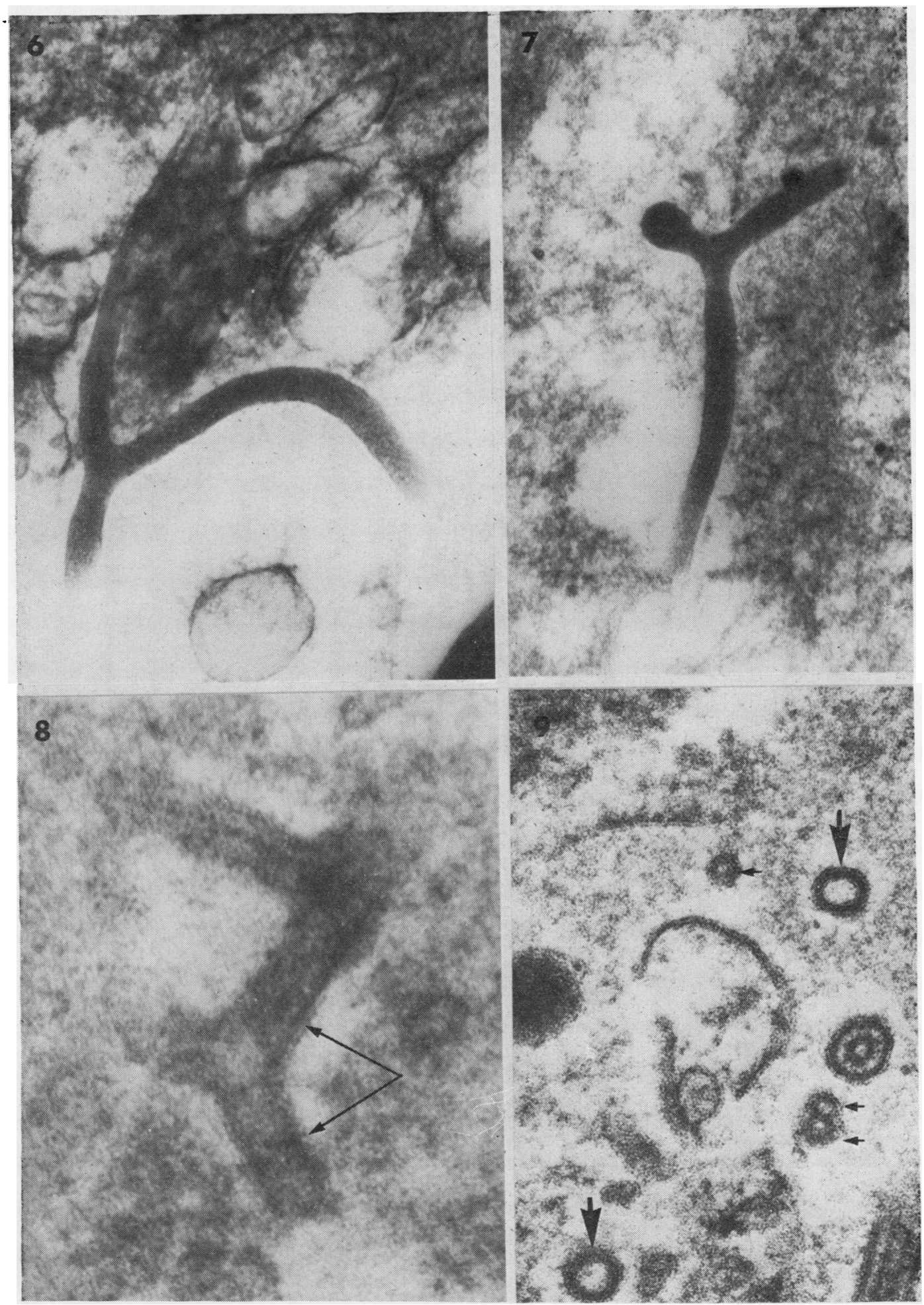

Figs 6, 7 Thicker sections cut to show branched forms in greater lengths. $(\times 60000)$

Fig. 8 Complex branching of virion. Surface spikes arrowed. $(\times 190000)$

Fig. 9 Section showing two forms without cores (thick arrows) and two cores without membrane coats, one doubled (thin arrows). Complete particle lies to right. $(\times 126000)$ 


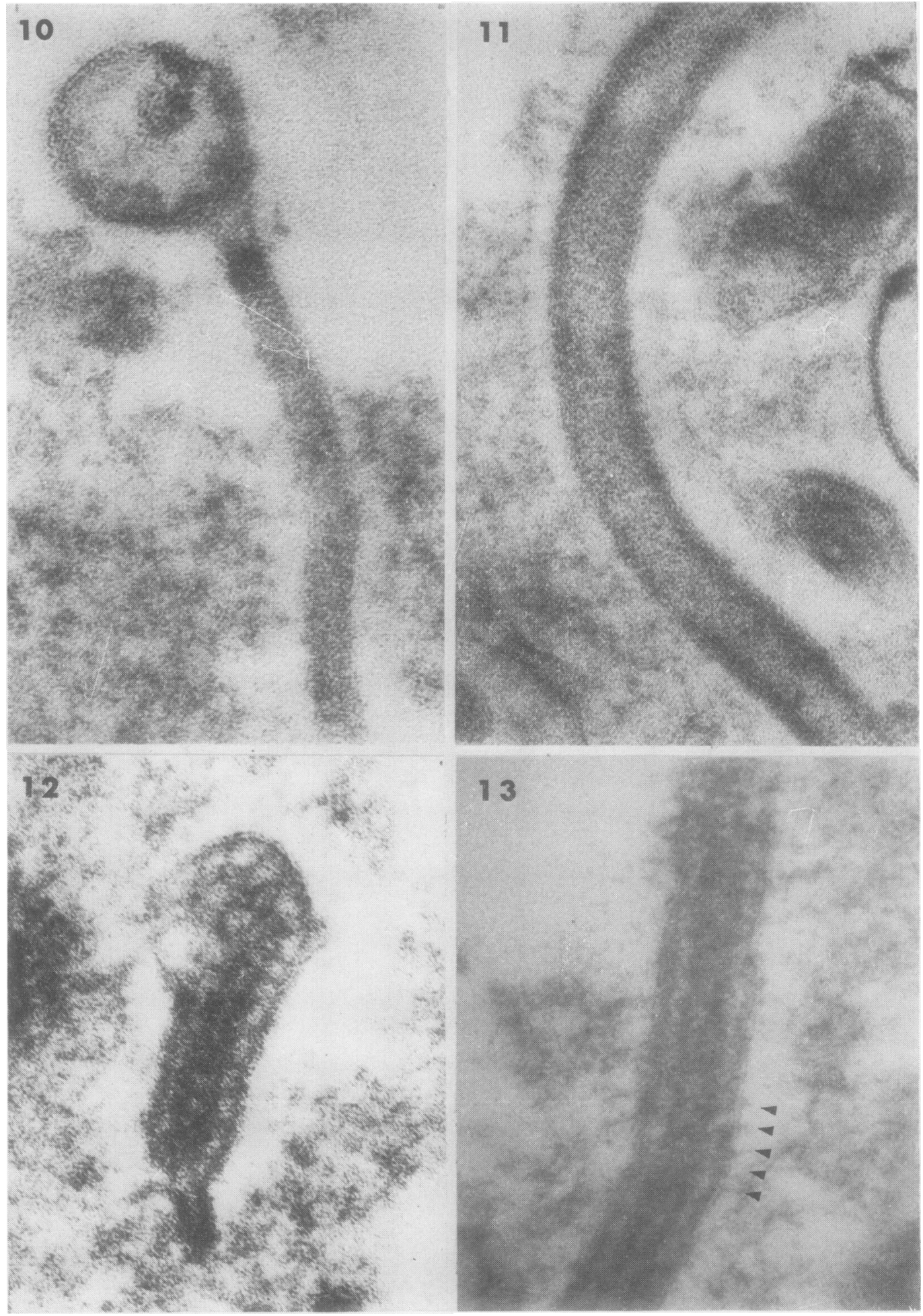

Fig. 10 Longitudinal section through particle with no coat, but which nevertheless has an 'enlarged head'. $(\times 200000)$

Fig. 11 Similar section through particle with no core. $(\times 200000)$

Fig. 12 Example of 'curled-up head'. ( $\times 200$ 000)

Fig. 13 Longitudinal section of complete virion, outer spikes arrowed. $(\times 200000)$ 


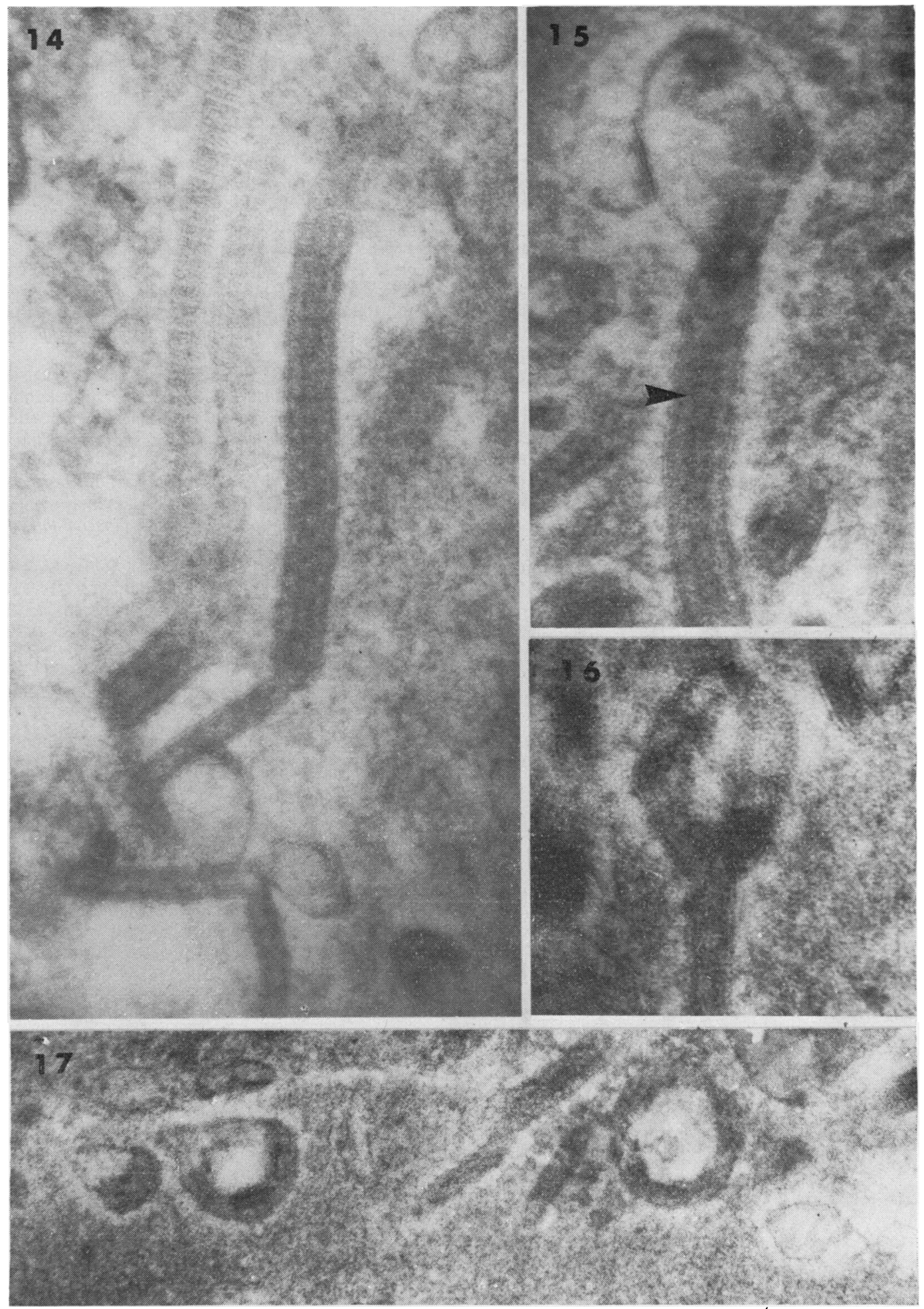

Fig. 14 Section with long virion, lower part of which contains no core. Collagen fibre to left of it. $(\times 126000)$ Fig. 15 'Enlarged head' with nucleic acid core partly curled up. 'Turns' of the nucleic acid helix arrowed. $(\times 200000)$

Fig. 16 Torus still attached to tubular body. $(\times 126000)$

Fig. 17 Several torus forms, one still has 'tag' from former attachment to main body. $(\times 80000)$ 


\section{References}

Almeida, J. D, Waterson, A. P., and Simpson, D. I. H. (1971). Morphology and morphogenesis of the Marburg agent. Marburg Virus Disease: Proceedings of a Symposium, edited by G. A. Martini and R. Siegert, pp. 84-97. Springer, Berlin and New York.

Bowen, E. T. W., Platt, G. S., Lloyd, G., Baskerville, A., Harris, W. J., and Vella, E. E. (1977). Viral haemorrhagic fever in southern Sudan and northern Zaire. Lancet, 1, 571-573.

Francis, D. P., Smith, D. H., Highton, R. B., Simpson, D. I. H., Lolik, P., Deng, I. M., Gillo, A. L., Idriss, A. A., and El Tahir, B. (1978). Viral haemorrhagic fever in the Sudan, 1976: epidemiological a spects of the disease. Bulletin of the World Health Organization (In press)

Gear, J. S. S., Cassel, G. A., Gear, A. J., Trappler, B., Clausen L., Meyers, A. M., Kew, M. C., Bothwell, T. H., Sher, R., Miller, G. B., Schneider, J., Koornhof, H. J., Gomperts, E. D., Isaäcson, M., and Gear, J. H. S. (1975). Outbreak of Marburg virus disease in Johannesburg. British Medical Journal, 4, 489-493.

Jo'nnson, K. M., Webb, P. A., Lange, J. V., and Murphy, F. A. (1977). Isolation and partial characterization of a new virus causing acute haemorrhagic fever in Zaire. Lancet, 1, 569-571.

Murphy, F. A., Simpson, D. I. H., Whitfield, S. G., Zlotnik, I., and Carter, G. B. (1971). Marburg virus infection in monkeys: ultrastructural studies. Labora- tory Investigation, 24, 279-291.

Pattyn, S., Jacob, W., van der Groen, G., Piot, P., and Courteille, G. (1977). Isolation of Marburg-like virus from a case of haemorrhagic fever in Zaire. Lancet, 1 , 573-574.

Peters, D., Muller, G., and Slenczka, W. (1971). Mor흠 phology, development and classification of the Marburg virus. Marburg Virus Disease: Proceedings of $a_{\triangle}^{\mathbb{D}}$ Symposium, edited by G. A. Martini and R. Siegert, pp. 68-83. Springer, Berlin and New York.

Ridley, D. S., Simpson, D. I. H., Francis, D. P., Smith, $\overrightarrow{0}$ D. H., Highton, R. B., Knobloch, J., Deng, I. M., Lolik, P., and El Tahir, B. (1978). Viral haemorrhagic fever in the Sudan, 1976: human pathology. Bulletin of the World Health Organization (In press)

Siegert, R., Shu, H-L., Slenczka, W., Peters, D., and ${ }^{\omega}$ Müller, G. (1967). Zur Ätiologie einer unbekannten, von Affen ausgegangenen menschlichen Infektions- N krankheit. Deutsche medizinische Wochenschrift, 92, 2341-2343.

Simpson, D. I. H. (1977). Marburg and Ebola virusinfections: a guide for their diagnosis, management and3

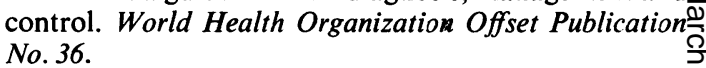

Smith, D. H., Francis, D. P., Highton, R. B., Simpson, $\overrightarrow{0}$ D. I. H., Deng, I. M., Lolik, P., Gillo, A. L., El Tahir, B., and Idriss, A. A. (1978). Viral haemorrhagic fever in the Sudan, 1976: clinical manifestations. Bulletin of the World Health Organization (In press) 